\title{
51. PHYSICAL PROPERTIES OF SEDIMENTS FROM THE JAPAN TRENCH MARGIN AND OUTER TRENCH SLOPE: RESULTS FROM DEEP SEA DRILLING PROJECT LEGS 56 AND 57
}

\author{
Bobb Carson, Department of Geological Sciences, Lehigh University, Bethlehem, Pennsylvania \\ and \\ Terry R. Bruns, U. S. Geological Survey, Menlo Park, California
}

\section{INTRODUCTION}

Physical properties of Japan margin sediments were determined not only to characterize the patterns of vertical consolidation in these deposits, but also to monitor the effect of subduction on the normal consolidation process. Previous studies (Lee and others, 1973; Bouma and Moore, 1975; Carson, 1977) have suggested that tectonic stress, manifested in the deformation complex of the inner trench slope, is reflected in the physical properties of the sediments. The Japan Trench was thought to represent a typical subduction zone (characterized by convergence rates of $8-10 \mathrm{~cm} / \mathrm{yr}$ ) in which this hypothesis could be tested.

Sites 438 and 439 (continental terrace) and 436 (outer trench slope) provide reference sections, dominated by normal vertical consolidation, which indicate the effects of lithology on physical properties at this margin. Sites $435,440,441,434$ are on the inner trench slope (from upper to lower slope, respectively), in that portion of the margin where tectonic modification of normal sediment consolidation might be anticipated.

Water content, bulk density, porosity, sonic velocity, and vane shear strength were determined for each site. Shipboard and laboratory methods used to determine these properties are summarized in the chapter on explanatory notes in this volume. The results are compiled in the Appendix (this volume, Part 1). In situ determinations of formation density, neutron porosity, and sonic velocity were made by down-hole geophysical logging at Sites 438,439 , and 440 . Only density and porosity were logged at Site 441 . The in situ geophysical logs are discussed in von Huene et al. (this volume). The physical properties are plotted together with lithologic and biostratigraphic data on the hole-summary charts (back pocket).

This chapter discusses the physical-property data by sites (in sequence, moving along the transect from west to east), compares the in situ logs with the shipboard determinations, and discusses the possible effects of subduction-induced tectonism on the physical nature of sediments on the inner trench slope.

\section{RESULTS}

\section{Sites $\mathbf{4 3 8}$ and $\mathbf{4 3 9}$}

These sites are on the outer margin of the broad, deep-sea terrace off northern Honshu. The lithologic column consists primarily of diatomaceous clay and claystone which is sandy and/or pebbly in the upper 100 meters. Below 830 meters, the sediment becomes increasingly enriched in volcanic ash (to a depth of $910 \mathrm{~m}$ ) and sand, and finally grades into massive sandstones at 1000 meters, and a dacite boulder-cobble conglomerate at 1100 meters.

The physical properties clearly reflect the lithologic variations at these sites (Figure 1). A marked density decrease from the surface $\left(1.7 \mathrm{Mg} / \mathrm{m}^{3}\right)$ to 100 meters $(1.35$ $\mathrm{Mg} / \mathrm{m}^{3}$ ) corresponds to a decline in sand content with increasing depth. Bulk density increases regularly (1.35 to $1.60 \mathrm{Mg} / \mathrm{m}^{3}$ ) from 100 to 560 meters. Below 560 meters, broad excursions $\left(\sim 0.15 \mathrm{Mg} / \mathrm{m}^{3}\right)$ in the density profile may be related to variations in either the diatom or carbonate content. A density low $\left(1.40 \mathrm{Mg} / \mathrm{m}^{3}\right)$ at 790 meters is apparently controlled not by lithology but by pervasive small-scale faults. The higher sand content below 820 meters results in markedly higher bulk densities $\left(1.65-2.1 \mathrm{Mg} / \mathrm{m}^{3}\right)$. A high degree of variability in the section below 920 meters reflects the lithologic inhomogeneity of sandstones and intercalated siltstones and, perhaps, local variations in cementation. Bulk densities in the conglomerate range from $2.2 \mathrm{Mg} / \mathrm{m}^{3}$ (clay matrix) to $2.4 \mathrm{Mg} / \mathrm{m}^{3}$ (dacite boulder). The deepest sediment recovered at Site 439 is a dark-gray claystone of density $2.5 \mathrm{Mg} / \mathrm{m}^{3}$.

Water contents and porosities reflect the density distribution. Water contents range from 7 to 65 per cent wet weight. Porosity varies from 10 to 84 per cent.

Sonic velocities show an overall increase from the surface $(1.6 \mathrm{~km} / \mathrm{s})$ to the base of the hole $(3.7 \mathrm{~km} / \mathrm{s})$, with deviations from a linear trend which are related to lithology. Velocity highs at 0 to 45 meters $(1.63-1.66 \mathrm{~km} / \mathrm{s})$ are related to high sand content, and between 830 and 850 meters are associated with disseminated volcanic ash.

The velocity determinations define a profile with well-grouped data to a depth of approximately $900 \mathrm{me}-$ ters. Somewhat more dispersed values $(1.7-2.7 \mathrm{~km} / \mathrm{s})$ are observed between 900 and 1050 meters, reflecting both the lithologic variation within a turbidite sequence and variable cementation in the massive sandstones. Below 1050 meters, in a zone which encompasses sandstones, limestones, and the dacitic conglomerates, the velocity is extremely variable, ranging from 1.7 to 4.8 $\mathrm{km} / \mathrm{s}$.

Shear strength, as defined by the Torvane and Wykeham-Farrance units (Figure 2), shows low $(<30 \mathrm{kPa})$ and somewhat variable values from 0 to 100 meters. Below 100 meters, however, the shear strength increases to 


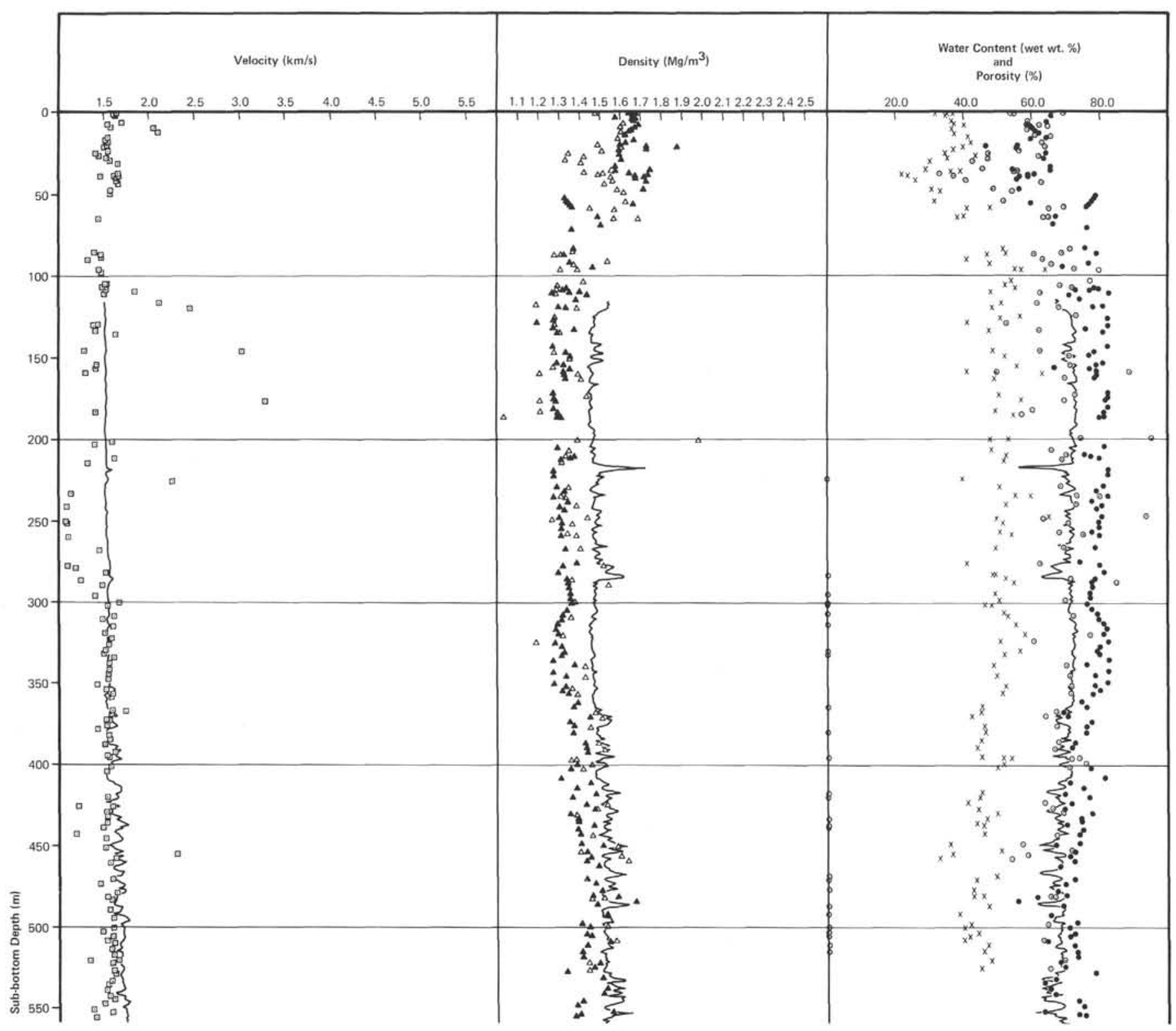




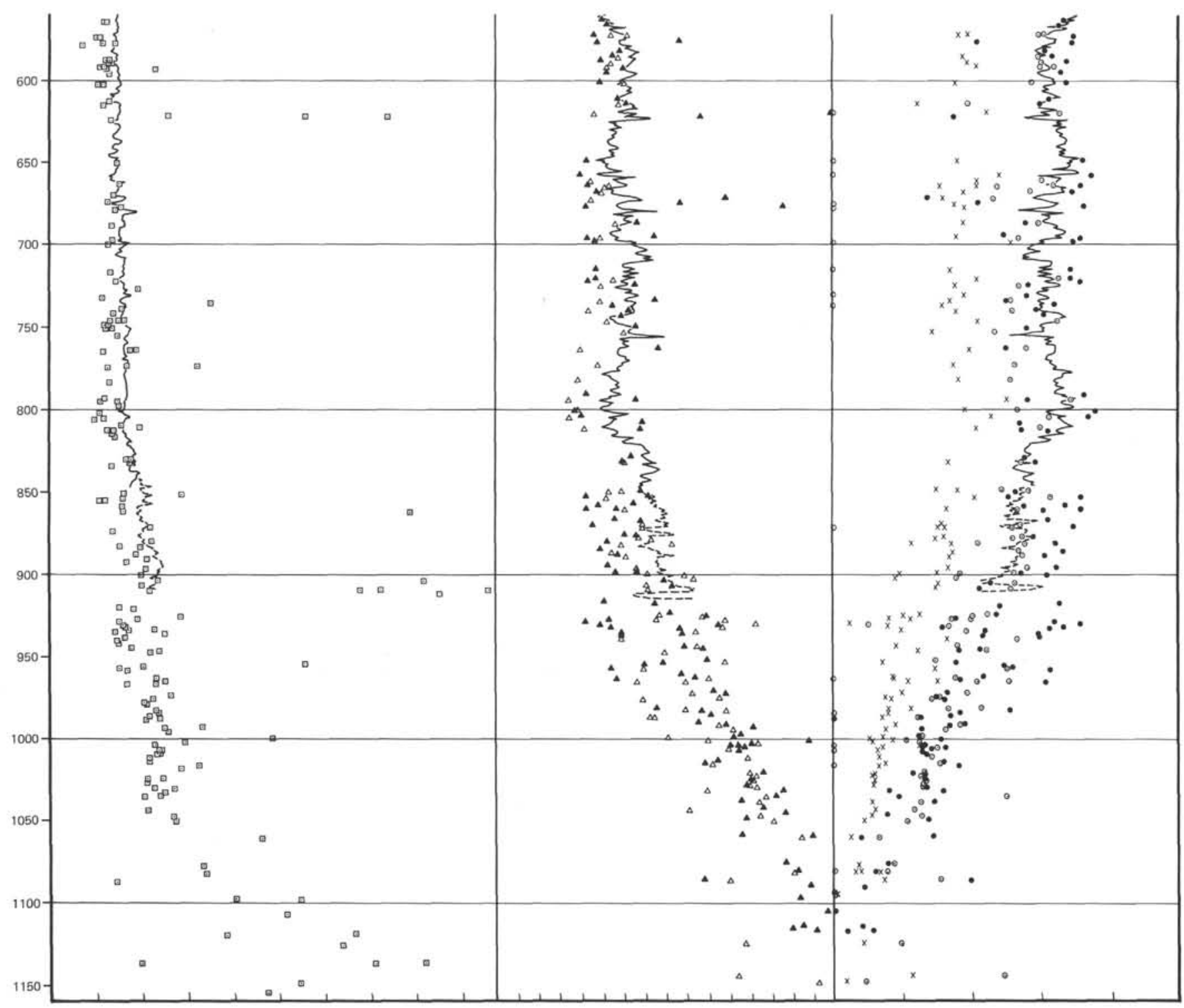

Figure 1. Sonic velocity, bulk density, water content, and porosity distributions, Sites 438 and 439 . Continuous lines represent processed in situ logs.

$\underset{\infty}{\bar{s}}$

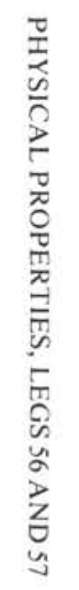




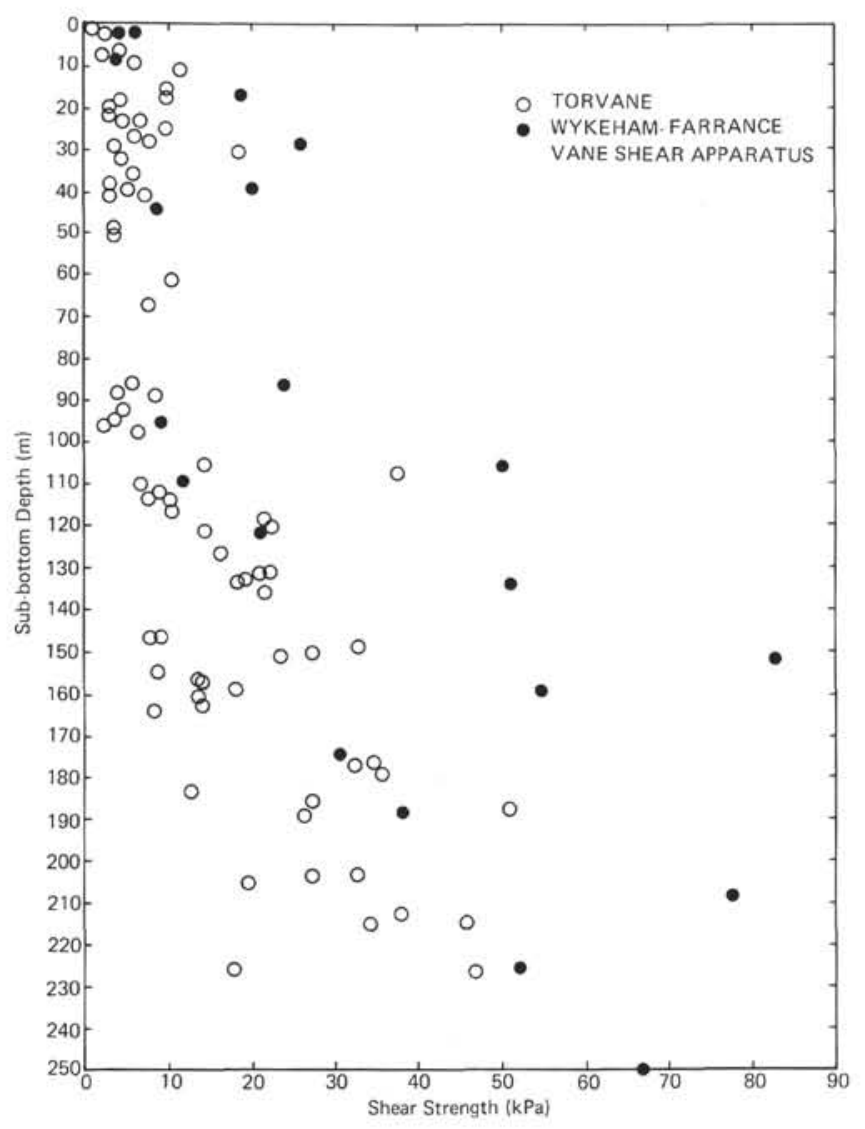

Figure 2. Shear strength, Site 438.

60 to $90 \mathrm{kPa}$, until failure occurs by fracturing (across the width of the core) rather than shearing at 260 meters.

\section{Site 435}

Site 435 is on the upper trench slope, approximately $100 \mathrm{~km}$ south and east of Sites 438 and 439 . The cored sediments are dominantly diatomaceous muds and mudstones. Volcanic shards and pebbles of pumice are abundant near the surface. Well-rounded igneous and argillite pebbles occur sporadically throughout the section, as do minor sand and ash horizons. Gas is present below 80 meters.

Physical properties at Site 435 are plotted in Figure 3. Bulk density shows an anomalous pattern: values between 0 and 75 meters average $1.45 \mathrm{Mg} / \mathrm{m}^{3}$, then rapidly drop to an average of $1.38 \mathrm{Mg} / \mathrm{m}^{3}$ at greater depths. Although this near-surface decline in density is similar to that observed at Sites 438 and 439 , it apparently is not controlled lithologically. The data reflect the presence of significant gas within the sediment. There is a slight increase in bulk density between 180 and 200 meters (to $1.46 \mathrm{Mg} / \mathrm{m}^{3}$ ); values below this level are greater than densities at corresponding depths at Sites 438 and 439.

Water content and porosity, in general, mirror the density distribution, although the discontinuity at 75 meters is not distinct in the porosity profile. Water contents range from approximately 43 per cent at the surface to about 57 per cent at 140 meters, decreasing to about 52 per cent at the bottom of the penetrated sec- tion. Porosity varies from 60 per cent $(40 \mathrm{~m})$ to about 75 per cent $(140 \mathrm{~m})$ and generally averages 65 to 70 per cent.

Sonic velocities are exceedingly uniform at this site and average $1.55 \mathrm{~km} / \mathrm{s}$. Very slight velocity highs occur at 80 to 95 meters $(1.60 \mathrm{~km} / \mathrm{s})$ and 150 to $190 \mathrm{~m}(1.62$ $\mathrm{km} / \mathrm{s}$ ). There is no apparent correlation between velocity and bulk density. The velocities are similar to those observed at Sites 438 and 439, except below 170 meters, where Site 435 velocities exceed $438 / 439$ values by approximately $0.1 \mathrm{~km} / \mathrm{s}$.

Shear strength, determined by Torvane only, increases regularly to a depth of 60 meters, where it is about $40 \mathrm{kPa}$ (Figure 4). This is considerably higher than the values recorded at Site $438(\sim 10 \mathrm{kPa})$. Below 60 meters, the data are variable, but generally show a constant shear strength of $50 \mathrm{kPa}$ (a value not obtained at Site 438 above a depth of 185 meters).

\section{Site 440}

This site is almost due east of Site 435, on the midslope terrace. Like Site 435 , Site 440 is characterized by a fairly uniform lithology of claystones and diatomaceous claystones ( $\leq 35 \%$ diatoms), although above 37 meters thin sand layers and pebbles of various lithologies are present. Below 260 to 280 meters, veins (apparently associated with dewatering; Arthur, von Huene, and Carson, this volume) and fractures become common and may locally control the physical properties.

Bulk density at Site 440 (Figure 5) does not show a simple increase with depth, although densities range from $1.55 \mathrm{Mg} / \mathrm{m}^{3}$ at the surface to $1.65 \mathrm{Mg} / \mathrm{m}^{3}$ at the bottom of the hole. Above 410 meters, density is highly variable $\left(0.15-0.2 \mathrm{Mg} / \mathrm{m}^{3}\right)$, which may reflect minor lithologic changes (such as diatom, silt, or ash content) not noted in visual examination of the cores, variations in degree of cementation (e.g., carbonate cement, 220-227 $\mathrm{m}$ and $257-265 \mathrm{~m}$ ), or variable gas content. Both the shipboard determinations (gravimetric and GRAPE) and the in situ logs are coincident and indicate a general density increase from the surface $(1.55$ $\left.\mathrm{Mg} / \mathrm{m}^{3}\right)$ to 260 meters $\left(1.70 \mathrm{Mg} / \mathrm{m}^{3}\right)$. From 260 to 410 meters, however, the shipboard values continue to increase to $1.80 \mathrm{Mg} / \mathrm{m}^{3}$, while the in situ data indicate a gradual decrease to $1.55 \mathrm{Mg} / \mathrm{m}^{3}$.

Both shipboard and in situ are in agreement from 410 meters (where the shipboard values abruptly decline to about $1.55 \mathrm{Mg} / \mathrm{m}^{3}$ ) to 570 or 620 meters. Within this interval, bulk density is essentially uniform. This zone defines a density low beneath the upper section and roughly coincides with the upper portion of the brecciated zone. Below 620 meters, bulk density increases to $1.80 \mathrm{Mg} / \mathrm{m}^{3}$, apparently in response to increasingly vitric and (or) calcareous deposits.

The densities observed at Site 440 deviate significantly from those at Sites 438, 439, and 435. Between 100 and 400 meters, bulk density at Site 440 is higher by at least $0.5 \mathrm{Mg} / \mathrm{m}^{3}$ (Site 435 ) or 0.2 to $0.4 \mathrm{Mg} / \mathrm{m}^{3}$ (Sites 438 and 439) at comparable depths, suggesting some degree of overconsolidation relative to the landward sites. In the low-density zone (410-620 m), densities at Sites 438 and 440 are comparable. Below 620 meters, the density at 


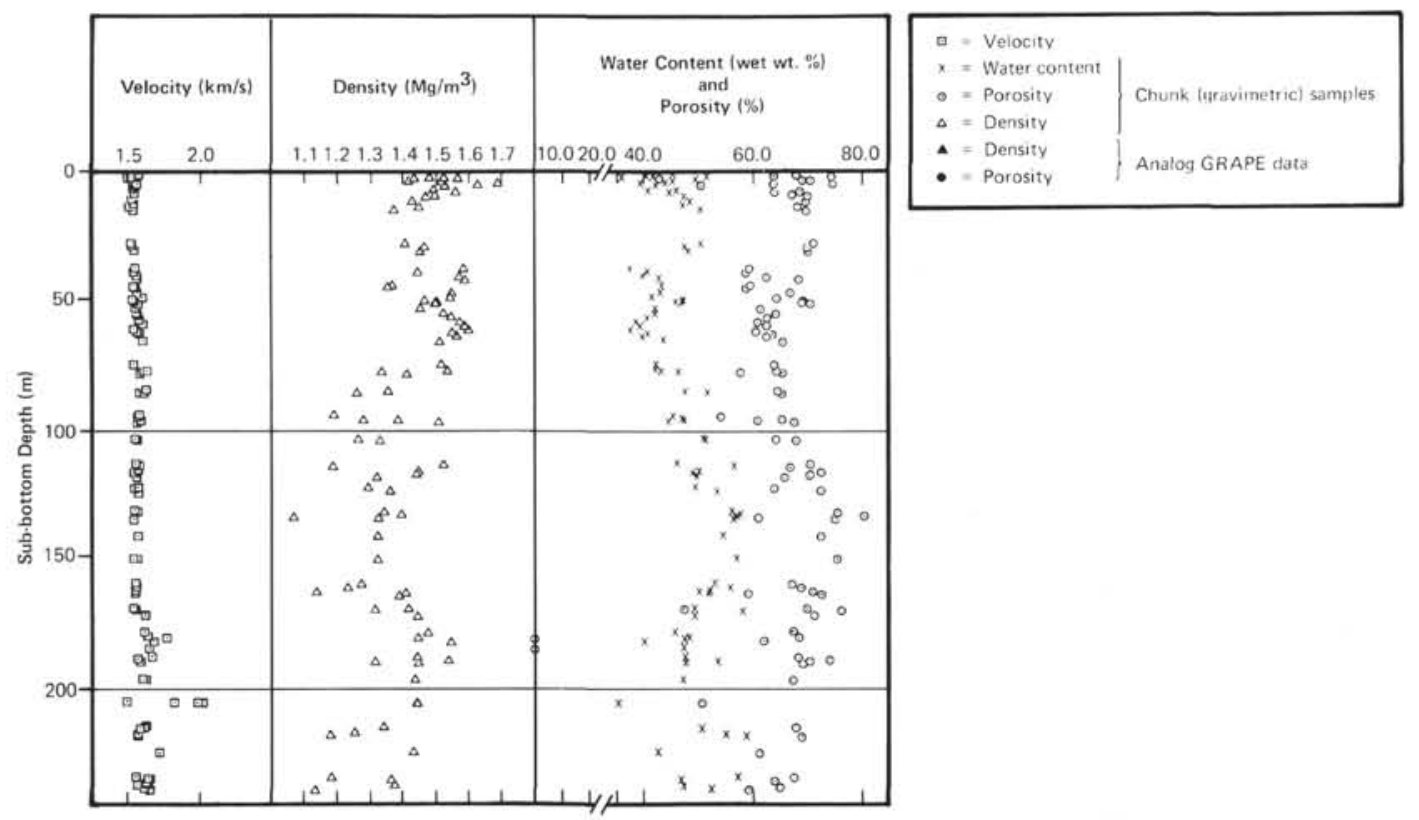

Figure 3. Sonic velocity, bulk density, water content, and porosity distributions, Site 435.

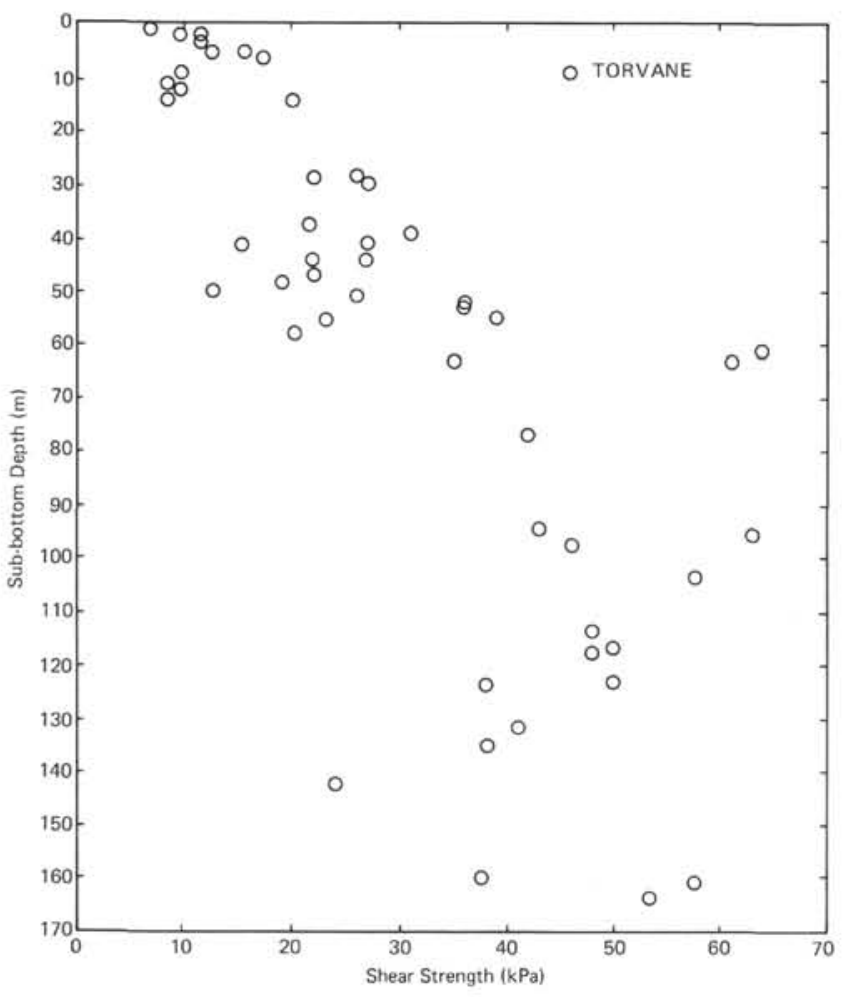

Figure 4. Shear strength, Site 435.

both sites increases, and values are approximately equal, although the data points are widely scattered.

Porosity at Site 440 (Figure 5) varies as the inverse of the density profile. Values decrease from 67 per cent at the surface to 63 per cent at 410 meters $(56 \%$ at $260 \mathrm{~m}$, in situ $\log )$. In the upper half of the brecciated zone (400-570 or 620 meters), porosity is constant at approximately 60 per cent and may reflect a fracture porosity in addition to interstitial porosity. Below this zone, the porosity declines to 54 per cent at the base of the hole. This interval is also brecciated, and the porosity decline may be controlled by compaction, closure of fractures, or lithologic and cementation variations.

Water content (Figure 5), which defines a profile similar to the porosity distribution, declines from 47 per cent at the surface to 30 per cent at 790 meters.

Sonic velocity increases gradually from $1.5 \mathrm{~km} / \mathrm{s}$ at the surface to $1.65 \mathrm{~km} / \mathrm{s}$ at 390 to 400 meters. The profile is characterized by low variability above 275 meters (Figure 5, in situ log) and increased noise below this depth. At 400 meters, both the shipboard determinations and in situ log show a rapid increase in velocity from 1.65 to $1.75 \mathrm{~km} / \mathrm{s}$. This transition occurs near the top of the low-density interval and the zone of brecciation, and also coincides with an inferred slump unit. Which of these factors exerts the controlling influence on velocity is not clear.

From 400 to 485 meters, velocities decrease very slightly $(1.75 \mathrm{~km} / \mathrm{s}$ in situ; $1.53-1.70 \mathrm{~km} / \mathrm{s}$ shipboard determinations) within the low-density zone. Below 485 meters, velocities increase uniformly to $2.0 \mathrm{~km} / \mathrm{s}$ at the base of the hole.

Sonic velocity bears little relationship to the bulkdensity distribution, a pattern which is also observed at 435 , but is contrary to the results at Sites 438 and 439 . At Site 440 , density maxima (e.g., 113-138 m) are not reflected in the velocity profile, nor is the low-density zone $(410-620 \mathrm{~m})$ uniquely defined by the velocity data. Furthermore, while sonic velocities are similar at the three sites near the surface, velocities at Site 440 are systematically greater than velocities at Sites 438 and 439 below 400 meters, by 0.15 to $0.20 \mathrm{~km} / \mathrm{s}$.

Shear strengths at Site 440 (Figure 6) show relatively high near-surface values (13-24 $\mathrm{kPa}$ ) and increase rapidly with depth to maxima (107-116 kPa) at depths of 95 to 115 meters. Shear strengths above 60 meters are comparable to those at Site 435 . However, at greater depths, 

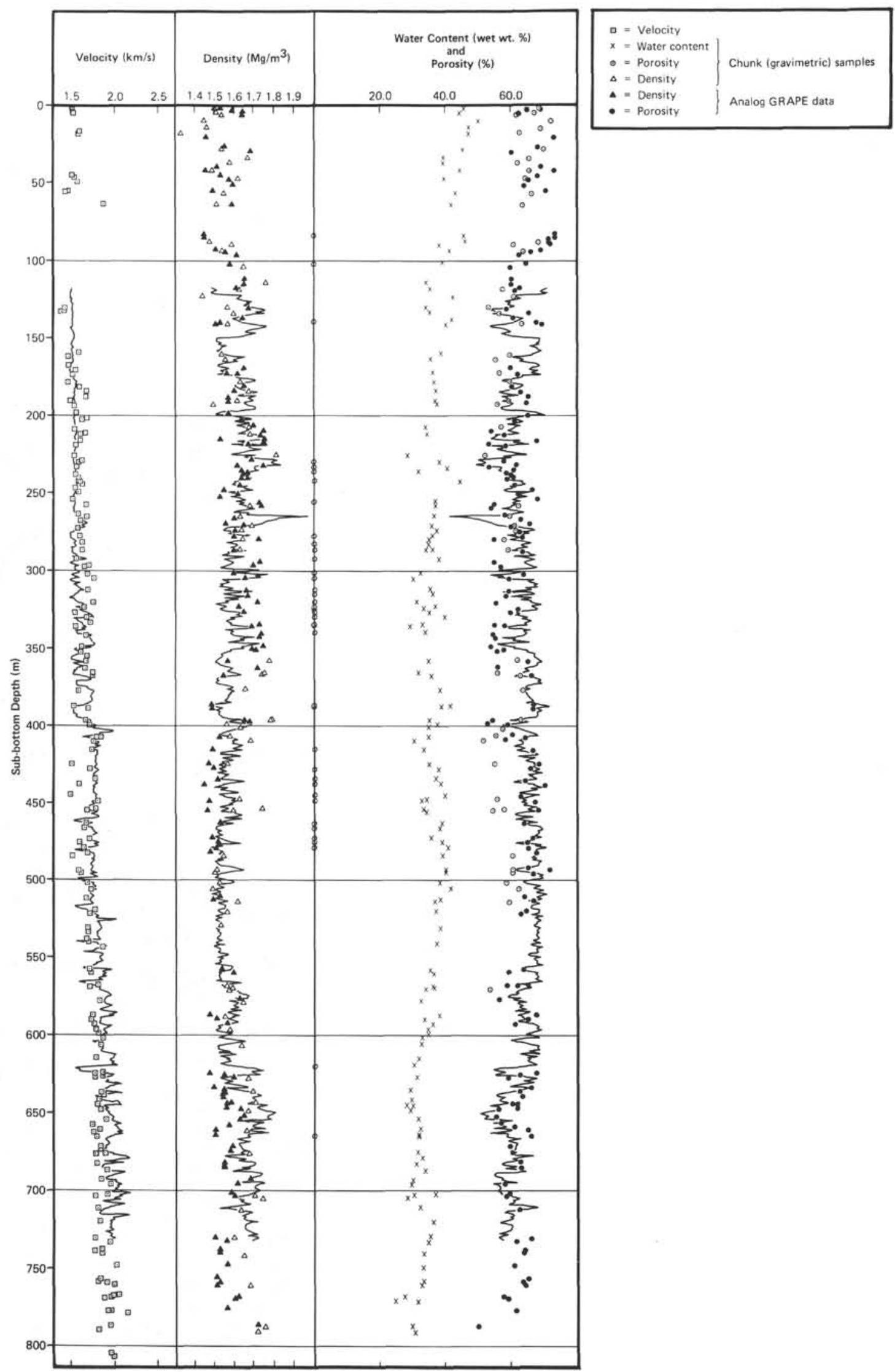

Figure 5. Sonic velocity, bulk density, water content, and porosity distributions, Site 440. Continuous lines represent processed in situ logs. 


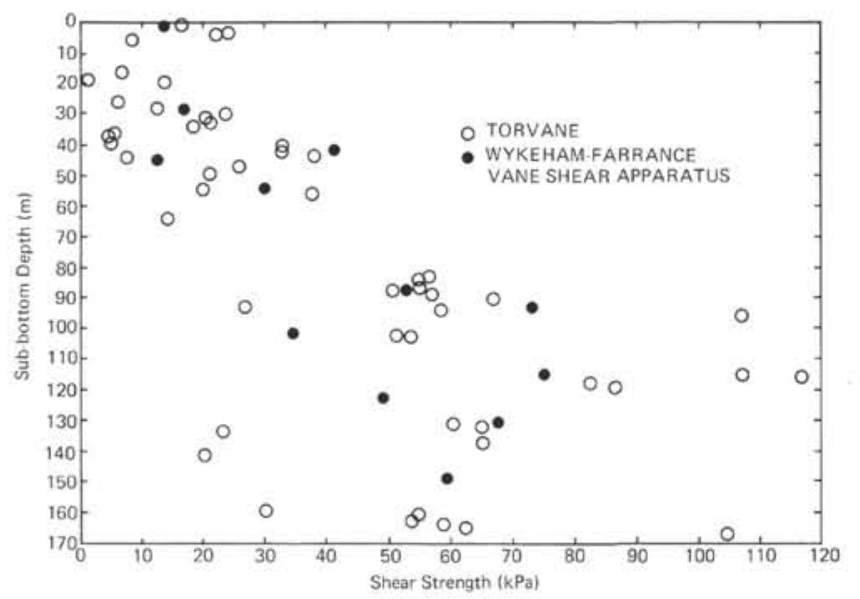

Figure 6. Shear strength, Site 440.

Site 440 maximum shear strengths are significantly greater $(>100 \mathrm{kPa})$ than those $(\leq 65 \mathrm{kPa})$ observed at Site 435 . Furthermore, Site 440 values are markedly greater than shear strengths at all comparable depths at Sites 438 and 439 . Indeed, the values are considerably higher than those given for typical hemipelagic-terrigenous sediment by Bouma and Moore (1975).

\section{Site 441}

At Site 441 , east of Site 440 on the lower trench slope, there was poor recovery of fissile diatomaceous claystone, claystone, and siltstone. As a result, shipboard determinations of physical properties are sparse (Figure 7). The only complete in situ record available is the formation-density log (and concomitant neutron porosity $\log$ ) which was run in Hole 441A. Faulting and brecciation are common below 250 meters.

Bulk densities increase from the surface $\left(1.55 \mathrm{Mg} / \mathrm{m}^{3}\right)$ to a maximum $\left(1.80 \mathrm{Mg} / \mathrm{m}^{3}\right)$ at about 220 meters (near the top of the fractured portion of the column), then decline to $1.54 \mathrm{Mg} / \mathrm{m}^{3}$ at 380 meters. This entire section is characterized by small density variations $(0.10-0.15$ $\left.\mathrm{Mg} / \mathrm{m}^{3}\right)$.

The section from 380 to 560 meters defines a lowdensity zone $\left(1.54 \mathrm{Mg} / \mathrm{m}^{3}\right)$. Within this interval, variability is minimal, with the exception of two large excursions $\left(1.90-2.1 \mathrm{Mg} / \mathrm{m}^{3}\right)$ which reflect siltstone breccias. There is a slight increase in density (1.54-1.57 $\mathrm{Mg} / \mathrm{m}^{3}$ ) from the top to the bottom of this interval.

Between the bottom of the in situ $\log (560 \mathrm{~m})$ and 575 meters, bulk density rapidly increases to about 1.8 $\mathrm{Mg} / \mathrm{m}^{3}$. This increase may reflect lithostatic control (low volcanic glass content, high clay content) or fracture closure.

The density profiles for Sites 440 and 441 are remarkably similar; both define a low-density ( 1.55 $\mathrm{Mg} / \mathrm{m}^{3}$ ) zone, and both indicate an inverse (declining) density gradient between about 250 and 400 meters. Both low-density zones exhibit exceedingly low $(<0.2$ $\mathrm{Mg} / \mathrm{m}^{3}$ ) density variability.

The porosity data (Figure 7), derived primarily from the density log, indicate that porosity varies from about 67 per cent at the surface to 69 per cent in the low- density interval $(380-560 \mathrm{~m})$ and falls to 20 to 43 per cent below 570 meters.

The few velocity determinations available for Site 441 indicate that sonic velocity increases from $1.53 \mathrm{~km} / \mathrm{s}$ at the surface to approximately $2.75 \mathrm{~km} / \mathrm{s}$ below 570 meters. The results are comparable to velocities observed at Site 440 , although the high $(\geq 2.5 \mathrm{~km} / \mathrm{s})$ values observed near the base of this site are significantly greater than those $(\sim 2.0 \mathrm{~km} / \mathrm{s})$ for Site 440 .

No shear-strength determinations were made at Site 441.

\section{Site $\mathbf{4 3 4}$}

This site is just east of Site 441, on the lower trench slope. Although recovery was somewhat better than at Site 441 , the fissile sediments did not allow frequent determination of physical properties. The sediments consist of muddy diatomaceous ooze $(0-101 \mathrm{~m})$ and diatomaceous mudstone and vitric diatomaceous mudstone (101-456 m) which are locally pebbly. A clayey tuffite dominates from 456 to 609 meters; the ash is dispersed throughout the sediment, as are pebbles. The deepest sediment encountered is vitric diatomaceous mudstone which also contains marlstone pebbles. Fracturing and (or) faulting is common to all sediment below 100 meters.

Bulk density (Figure 8) increases from $1.3 \mathrm{Mg} / \mathrm{m}^{3}$ at the surface to about $1.9 \mathrm{Mg} / \mathrm{m}^{3}$ at the base of the hole $(650 \mathrm{~m})$. The increase is not uniform, and the data define a modest density high $\left(1.75 \mathrm{Mg} / \mathrm{m}^{3}\right)$ at 280 to 320 meters. This interval is underlain $(320-450 \mathrm{~m})$ by a zone of slightly lower densities $\left(1.65-1.70 \mathrm{Mg} / \mathrm{m}^{3}\right)$ above a zone of higher $\left(1.8-1.9 \mathrm{Mg} / \mathrm{m}^{3}\right)$ values at the base of the hole.

The density profile at Site 434 appears to differ significantly from those at Sites 440 and 441 . Although density values are approximately equal at all three sites between 0 and 100 meters, at greater depths there are notable disparities: between 100 and 250 meters, Site 434 densities are consistently lower than Site 440 and 441 densities by $0.1 \mathrm{Mg} / \mathrm{m}^{3}$; below 300 to $350 \mathrm{~m}$, however (i.e., from the top of low-density zones in Sites 440 and 441), Site 434 densities exceed Sites 440 and 441 densities by 0.1 to $0.3 \mathrm{Mg} / \mathrm{m}^{3}$. With respect to Sites 438 and 439 , the bulk density at Site 434 (below $260 \mathrm{~m}$ ) is greater by 0.2 to $0.3 \mathrm{Mg} / \mathrm{m}^{3}$.

Densities below 250 meters indicate considerable overconsolidation relative to the other sites. Furthermore, the high densities $\left(\geq 1.7 \mathrm{Mg} / \mathrm{m}^{3}\right)$ occur over the same interval in which faulting or brecciation are common (Arthur, Carson, and von Huene, this volume). This pattern suggests that sediments at Site 434 have been subject to tectonically induced dewatering.

The porosity and water-content data generally mirror the density profile (Figure 8 ), although the density high from 280 to 320 meters is not well defined. Water content decreases from 55 per cent at the surface to 20 per cent at the base of the hole. Over the same interval, porosities range from 70 to 40 per cent.

Sonic velocity is low $(1.50-1.55 \mathrm{~km} / \mathrm{s})$ from the surface to 100 meters, where it increases abruptly to 1.65 


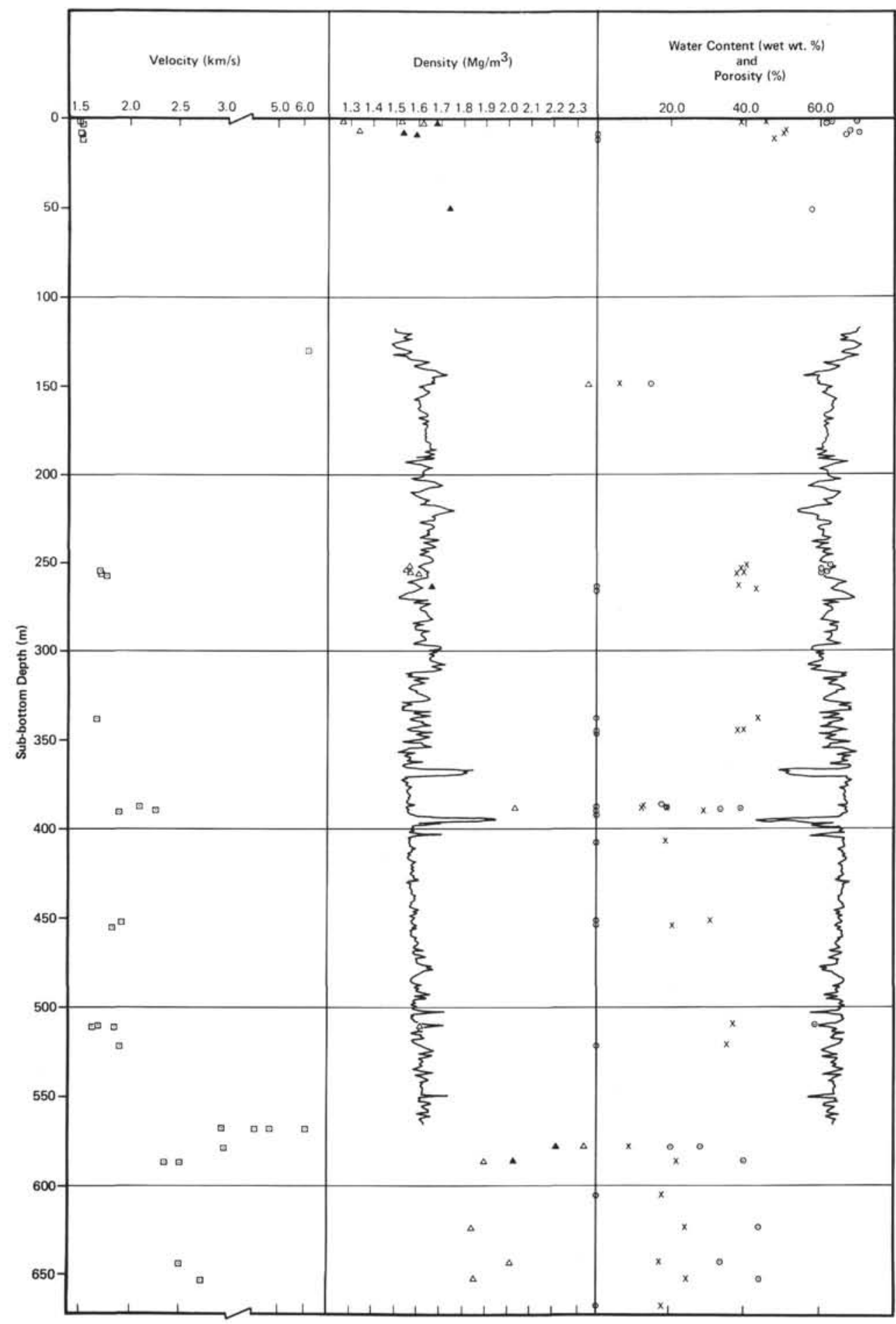

Figure 7. Sonic velocity, bulk density, water content, and porosity distributions, Site 441. Continuous lines represent processed in situ logs.

$\mathrm{km} / \mathrm{s}$, increasing then more gradually to $1.70 \mathrm{~km} / \mathrm{s}$ at 320 meters. Velocities are notably lower $(1.60 \mathrm{~km} / \mathrm{s})$ from 320 to 500 meters, corresponding to the zone of lower densities. Below 500 meters, velocity increases regularly to $2.0 \mathrm{~km} / \mathrm{s}$ at the base of the hole.

The velocity profile at this site is similar to that at Site 441 , although velocities at Site 434 are higher $(0.1-0.2$ $\mathrm{km} / \mathrm{s}, 100-300 \mathrm{~m})$ or lower $(0.1-0.2 \mathrm{~km} / \mathrm{s}, 390-500 \mathrm{~m})$ in some sections. Unlike Site 440 , however, the velocity determinations at this site clearly define the low-density zone from 320 to about 500 meters. In general, velocities at Site 434 are greater than those observed at Sites 438 and 439 by 0.1 to $0.4 \mathrm{~km} / \mathrm{s}(100-320 \mathrm{~m}, 520 \mathrm{~m})$. Near the surface $(0-100 \mathrm{~m})$, and at middle depths (320$520 \mathrm{~m}$ ), the velocities at the two sites are equivalent.

Poor recovery at this site restricted the number of Torvane shear-strength determinations (Figure 9). Values range from $4 \mathrm{kPa}$ at the surface to $54 \mathrm{kPa}$ at 8 me- 


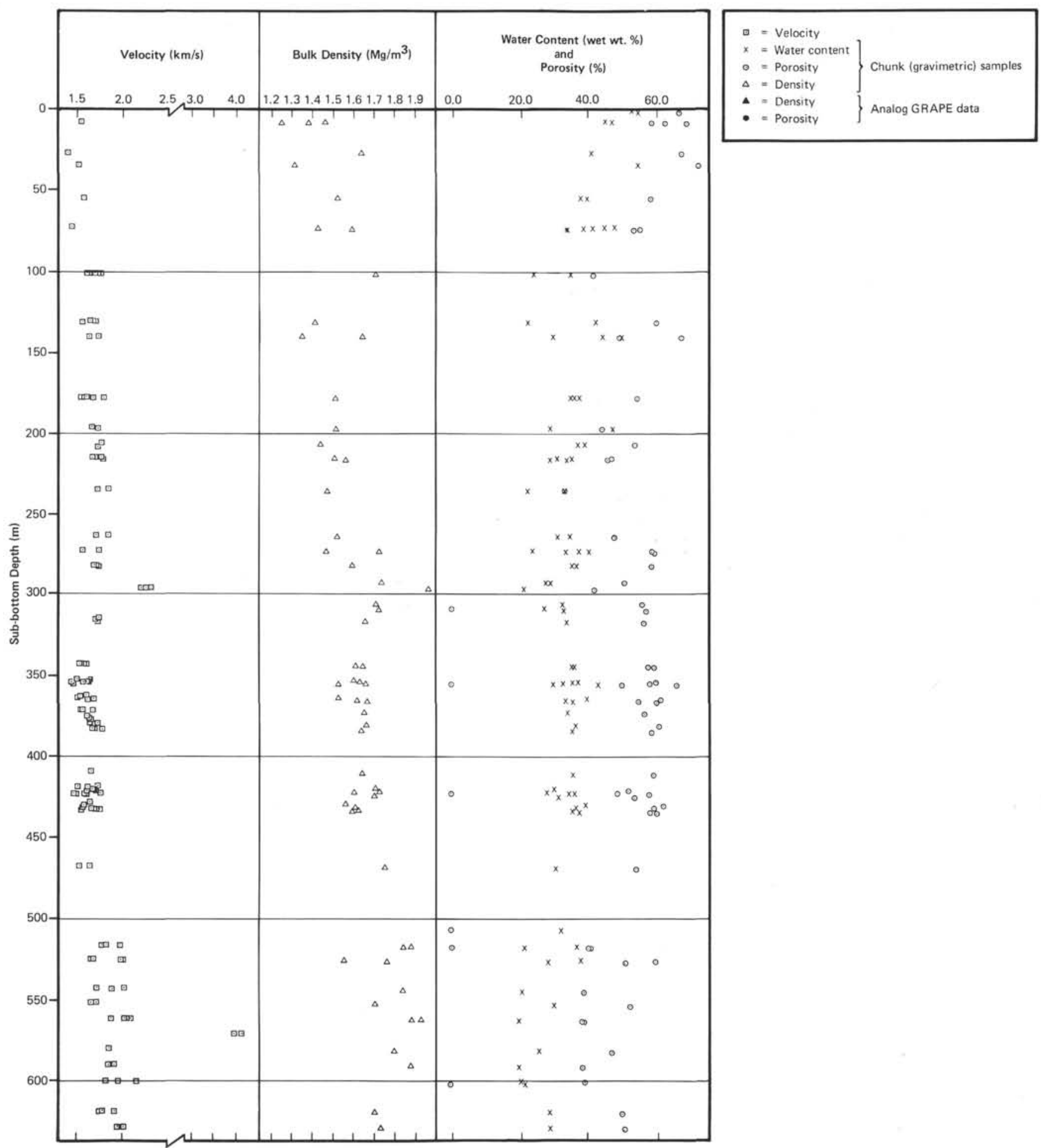

Figure 8. Sonic velocity, bulk density, water content, and porosity distributions, Site 434.

ters. Values above $40 \mathrm{kPa}$ were not observed at depths less than 42 meters at any other site on Leg 56 or 57 . These data imply that surficial sediments are also anomalously overconsolidated at this site, although this condition is not indicated by bulk density.

\section{Site $\mathbf{4 3 6}$}

Site 436 , on the outer trench slope, is about $120 \mathrm{~km}$ east and north of Site 434, and constitutes the Pacific plate reference section. The sediments consist of vitric 


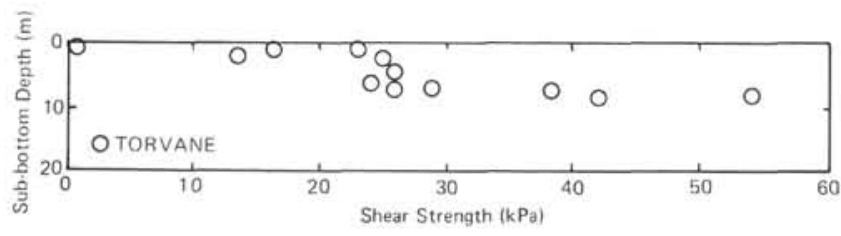

Figure 9. Shear strength, Site 434.

diatomaceous muds or muddy oozes $(0-312 \mathrm{~m})$, radiolarian diatomaceous mudstones $(312-360 \mathrm{~m})$, and pelagic clay and chert (360-397 m).

Bulk density (Figure 10) shows little variation in the upper 250 meters of the hole, averaging $1.43 \mathrm{Mg} / \mathrm{m}^{3}$. There is a decrease in density at 103 meters to about 1.35 $\mathrm{Mg} / \mathrm{m}^{3}$, which corresponds to an increase in diatom content from about 15 to 30 per cent. The low density persists to about 240 meters and encompasses (165-245 m) a zone of vitric mud. Below 245 meters, both the diatom and volcanic-glass content decline, and density increases regularly to about $1.5 \mathrm{Mg} / \mathrm{m}^{3}$ at 360 meters. Bulk density increases markedly in the pelagic clay (1.7 $\left.\mathrm{Mg} / \mathrm{m}^{3}\right)$ and chert $\left(1.75 \mathrm{Mg} / \mathrm{m}^{3}\right)$ in the lowermost part of the hole.

Bulk density above 250 meters at Site 436 is in general equal to, or slightly less than, comparable densities at Sites 440, 441, and 434. At greater depths (250-400 m), however, the density at Site 434 is greater by 0.1 to 0.3 $\mathrm{Mg} / \mathrm{m}^{3}$. This disparity is attributable to the low-density zones observed at Sites 440,441 , and 434 between approximately 300 and 600 meters, rather than to particularly high densities at Site 436 . Near-surface $(0-100 \mathrm{~m})$ densities at Site 436 are lower $\left(\leq 0.3 \mathrm{Mg} / \mathrm{m}^{3}\right)$ than at comparable depths at Sites 438 and 439. Below 275 meters, however, in radiolarian diatomaceous mudstones, pelagic clay, and chert, bulk densities at Site 436 consistently exceed densities at Sites 438 and 439 (diatomaceous mudstone) by $\geq 0.3 \mathrm{Mg} / \mathrm{m}^{3}$.

Porosity and water-content, like bulk density, show minor fluctuations which are related to lithologic variations. In general, however, there is a regular decline in porosity $(70-55 \%)$ and water content $(50-37 \%)$ from the surface to the bottom of the hole.

Sonic velocity increases rather uniformly from 1.50 $\mathrm{km} / \mathrm{s}$ at the surface to $1.65 \mathrm{~km} / \mathrm{s}$ near the base of the hole. Minor fluctuations $(\leq 0.5 \mathrm{~km} / \mathrm{s})$ at 245 and 360 meters reflect lithologic control (variation in biogenic material).

Velocities recorded at this site are generally lower (by $0.1-0.2 \mathrm{~km} / \mathrm{s}$ ) than velocities of the inner trench slope (Sites 440, 434). Velocities at Sites 438 and 439 and 436 are equivalent.

Shear strengths (Figure 11), as determined by the Torvane, increase regularly from $6 \mathrm{kPa}$ at the surface to

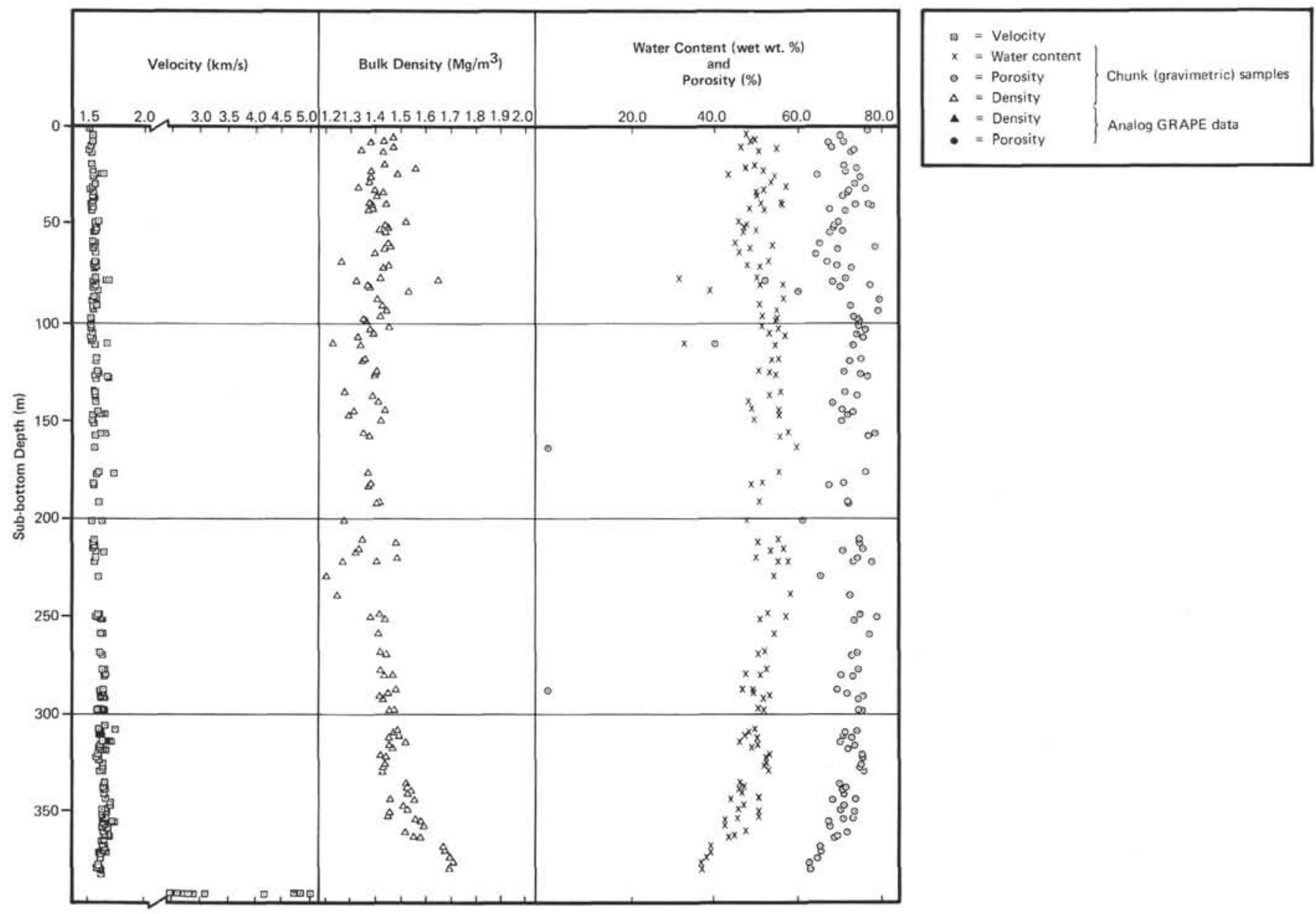

Figure 10. Sonic velocity, bulk density, water content, and porosity distributions, Site 436. 


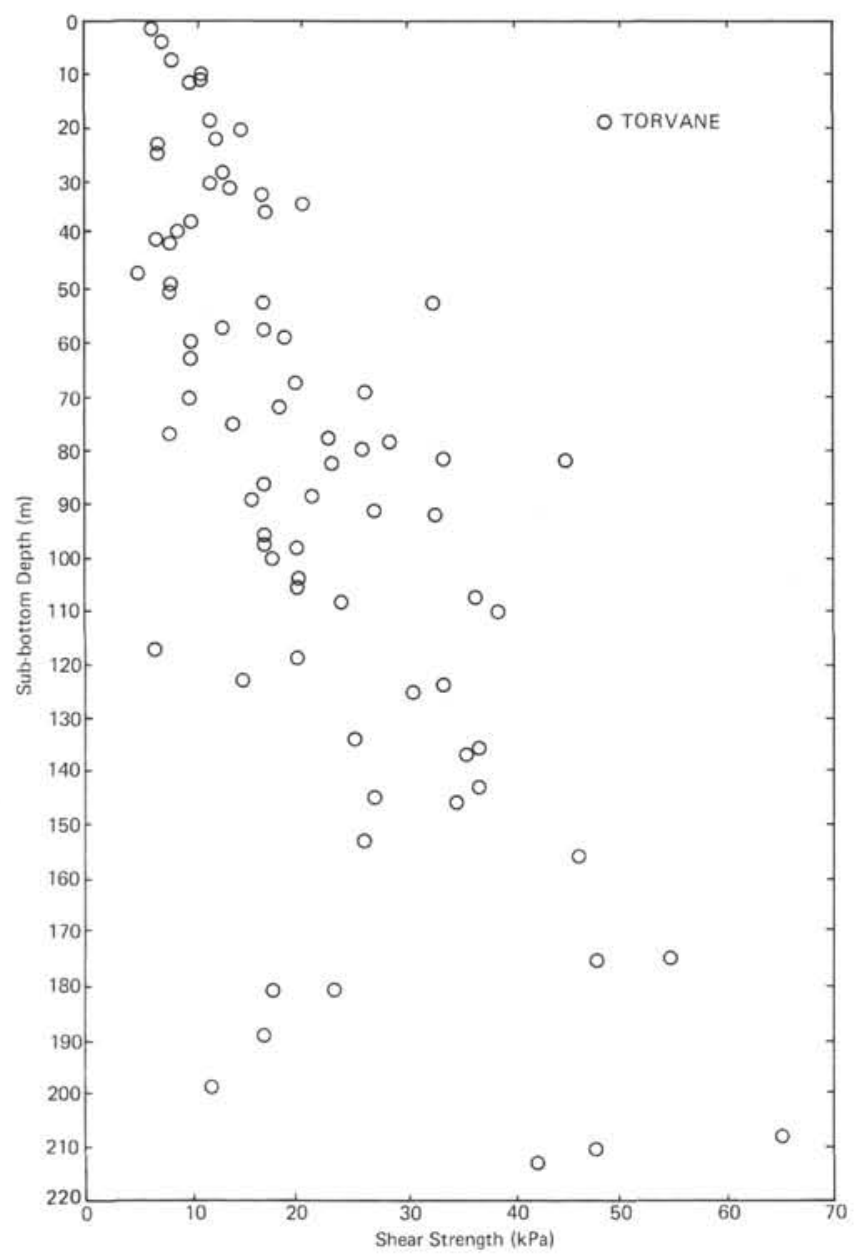

Figure 11. Shear strength, Site 436.

$65 \mathrm{kPa}$ at 180 meters. These values are slightly higher $(\leq 10 \mathrm{kPa})$ than those from similar determinations at Site 438 , but are significantly lower $(14-75 \mathrm{kPa})$ than shear strengths observed in sediments of the inner trench slope (Sites 435, 440, 434).

Figure 12 compares bulk densities and sonic velocities at the seven sites.

\section{DISCUSSION}

Shipboard versus in situ Determinations of Sonic Velocity and Wet-Bulk (formation) Density: Sites 438, 439 , and 440

\section{Bulk Density}

Shipboard determinations of bulk density at Sites 438 and 439 are systematically lower than in situ (geophysical- $\log$ ) values by 0.2 to $0.3 \mathrm{Mg} / \mathrm{m}^{3}$ (Figure 1 ). This discrepancy is due, at least in part, to assigning a grain density $\left(2.65 \mathrm{Mg} / \mathrm{m}^{3}\right)$ in $\log$ processing which is unrealistically high with respect to measured grain densities $\left(\sim 2.50 \mathrm{Mg} / \mathrm{m}^{3}\right)$. It should be noted, however, that high in situ densities are characteristic of diatomaceous deposits even when correct grain densities are used in log processing (Stosur and David, 1975).

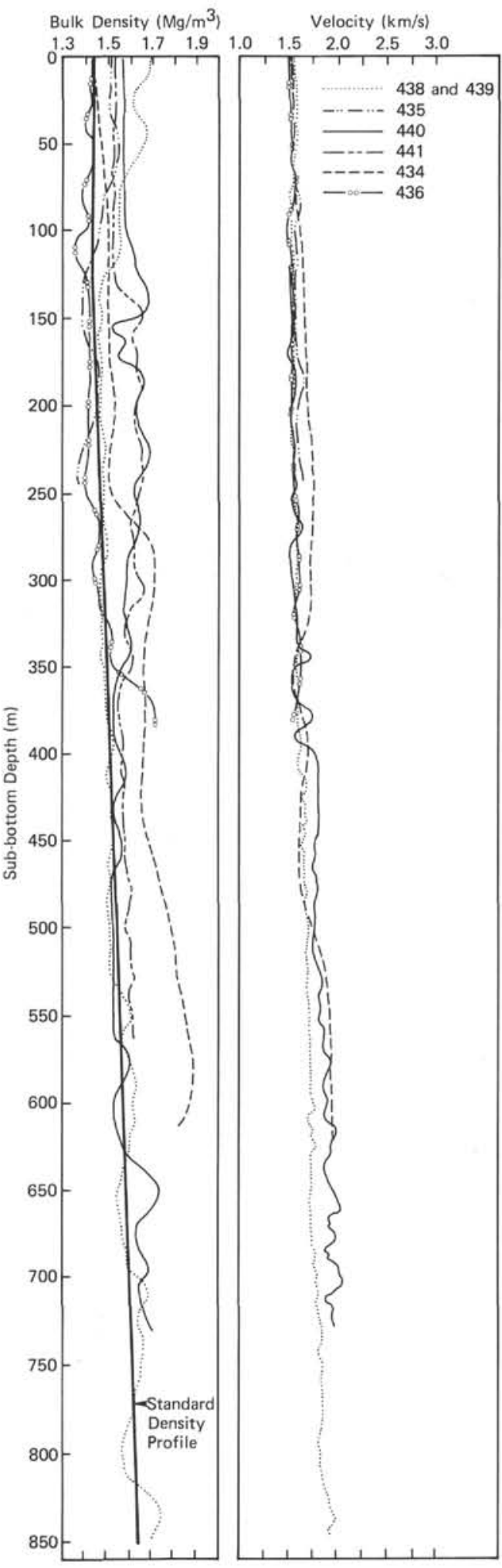

Figure 12. Bulk-density and sonic-velocity profiles, Legs Legs 56 and 57. Bulk densities for Sites 438 and 439, 440 , and 441 are taken from processed formation-density log. Density profiles for Sites 434, 435, and 436 are based on shipboard GRAPE and gravimetric determinations. Sonic velocities for Sites 438 and 439 and 440 are based on processed sonic logs. Velocitites for Sites 434,435 , and 436 were determined on recovered samples. Profiles are visual estimates of data distribution. 
The diatom content at Site 440 is lower than at Sites 438 and 439 , and there is not constant disparity between in situ and shipboard bulk densities at this site (Figure 5). Agreement is good above 250 meters, where measured grain densities average $2.61 \mathrm{Mg} / \mathrm{m}^{3}$.

Between 250 and 390 meters at Site 440 , however, shipboard bulk densities are consistently higher $(0.10$ $0.15 \mathrm{Mg} / \mathrm{m}^{3}$ ) than in situ values (Figure 5). This is an interval of constant shipboard values but declining in situ densities. The shipboard values decline rapidly at 400 meters, at which point both data sets give equivalent results. The disparity cannot be attributed to use of incorrect $\left(2.65 \mathrm{Mg} / \mathrm{m}^{3}\right)$ grain density in log processing, as substitution of the appropriate value $\left(2.50 \mathrm{Mg} / \mathrm{m}^{3}\right)$ would result in a further reduction of in situ density, and an even larger discrepancy between the two sets of data.

The disparity may be due to the fracturing observed in this interval (von Huene and others, this volume). Above 250 meters at Site 440 , no faults are present. A few fractures (unrelated to drilling deformation) are observed between 250 and 400 meters. It is possible that widely spaced ( $\geq 1 \mathrm{~m}$ ?) fractures, which do not affect shipboard density determinations, are reflected in the in situ values. If so, the pattern of generally declining in situ densities implies that the fracture porosity (and hence the fracture density) increases down this section. At approximately 400 meters the spacing of fractures may become so small $(\leq 1 \mathrm{~cm})$ that shipboard determinations of density also decrease. (This is corroborated by the pattern of veining and fracturing described by von Huene and others in this volume.)

The reader is cautioned, however, that no direct measurement of the effect of fracturing on density or porosity has been made. From 440 to 625 meters, in situ and shipboard values are equivalent. Over most of this interval, values are constant at $1.55 \mathrm{Mg} / \mathrm{m}^{3}$, but below 570 meters the density increases to about $1.65 \mathrm{Mg} / \mathrm{m}^{3}$ at 625 meters, suggesting that fractures are closed or annealed, presumably by lithostatic load.

Below 625 meters, in situ density values are again systematically high by 0.1 to $0.15 \mathrm{Mg} / \mathrm{m}^{3}$. This disparity results from application of unrealistically high grain density in log processing (2.65 versus actual 2.41 $\left.\mathrm{Mg} / \mathrm{m}^{3}\right)$.

\section{Sonic Velocity}

Comparison of shipboard (Hamilton-frame) and in situ (geophysical-log) velocity determinations at Sites 438 and 439 is not possible above 110 meters, as no in situ values are available. Nevertheless, the shipboard values reasonably extrapolate the velocity gradient defined by the upper portion of the in situ profile.

Between 110 and 300 meters at Sites 438 and 439, shipboard velocity determinations are highly variable and generally low with respect to the in situ velocities. This pattern is undoubtedly due to the semiconsolidated nature of the sediment: reliable determinations could not be made through the core liner, because of very high signal attenuation, and the sediment was too soft to be cut from the core for velocity determination on a chunk sample. This difficulty was encountered at every site.
Shipboard velocity determinations below 400 meters are systematically lower than in situ values, by $0.1 \mathrm{~km} / \mathrm{s}$ at 400 meters to $0.3 \mathrm{~km} / \mathrm{s}$ near the base of the hole. The cause of this disparity is unknown. However, the progressive increase in the discrepancy suggests that, at least in diatom-rich deposits, sample rebound due to removal of hydrostatic and lithostatic pressure may significantly affect velocities, although physical rebound is notably low in siliceous sediments (Hamilton, 1976).

The velocity profile at Site 440 shows a pattern similar to that at Sites 438 and 439 below 400 meters (i.e., shipboard velocity < in situ velocity). Above 400 meters, however, the shipboard values exceed in situ velocities at this site. This pattern may reflect (as did the density distribution) widely spaced ( $\geq 1 \mathrm{~m}$ ?) fractures which might reduce in situ velocities, but have little or no affect on shipboard values. When the spacing of the fractures decreases (at 400 meters) to a scale of centimeters, shipboard determinations are affected, and in situ velocities exhibit much lower variability with respect to shipboard determinations.

\section{Tectonic Modification of Physical Properties on the Inner Trench Slope}

Both reference sections (Sites 438 and 439, Japan deep-sea terrace, and Site 436, outer trench slope) show a general increase in bulk density and sonic velocity, and a concomitant decrease in porosity and water content, with increasing depth. Minor fluctuations in these patterns can be attributed to lithologic control (variations in sediment texture, diatom content, and (or) grain density). These data imply that consolidation at these two sites has been effected primarily by vertical compaction under lithostatic load.

The sites of the inner trench slope $(440,441,434)$ with sufficient physical-property data exhibit profiles which contrast markedly with Sites 438 and 439 and 436. Furthermore, the similarity of these inner-trench profiles implies a uniform pattern of consolidation on this portion of the margin, where tectonic stress as well as lithostatic load may affect the deposits.

Sites 440, 441, and 434 (Figures 5, 7, and 8) all exhibit a low-density zone between about 250 and 550 meters. Where down-hole logs are available (Sites 440 and 441; Figures 5,7 ), bulk density decreases gradually from a maximum $\left(1.70-1.80 \mathrm{Mg} / \mathrm{m}^{3}\right)$ at about 250 meters to a minimum $\left(1.55 \mathrm{Mg} / \mathrm{m}^{3}\right)$ at about 400 meters. Shipboard determinations simply define a rapid decrease in density at 400 meters ( $300 \mathrm{~m}$ at Site 434$)$. Both in situ and shipboard determinations, however, define a 150-200-meter -thick section of uniform low density, below which the density increases very rapidly. The top of the low-density zone shoals eastward toward the trench, from 410 meters (Site 440) to 380 meters (Site 441) to about 300 meters (Site 434).

The zone of low density does not correspond to recognizable variations in lithology, and shows only a casual correlation with the observed distribution of veins and fractures (von Huene, et al., this volume).

The significance of the low-density zone cannot be evaluated fully with the available data. However, it may have important implications for convergent-margin sed- 
iment-consolidation history, sedimentary fabric, and structures. Some of the obvious possibilities are considered in the following.

Numerous studies (Hottman and Johnson, 1965; Reynolds, 1970; Fertl, 1976; and others) indicate that reverse density gradients and low-density zones are indicative of underconsolidated sediments and are commonly characterized by abnormal pore pressures. Most recognized occurrences of abnormal fluid pressures result from lithostatic loading of sediments which are capped by relatively impervious rocks (limestone, shale, salt, etc.). The lithologies at Sites 440, 441, and 434, however, consist of relatively uniform diatomaceous mudstones. If the low-density zones observed at these sites are overpressured, then isolation of fluid pressures at depth (from normal hydrostatic pressure) occurs for some reason other than lithologic variation.

The extensive fractures (von Huene and others, this volume) and the character of the shipboard and in situ density distributions suggest that a fracture porosity which dies out toward the surface exists in these sediments. If so, then the unfractured, near-surface diatomaceous mud may constitute the "impervious" lithology required to disrupt the normal hydrostatic pressure gradient.

Below the low-density zone at Sites 440,441 , and 434 , bulk density increases significantly (by $0.1-0.3$ $\mathrm{Mg} / \mathrm{m}^{3}$ ). If the low bulk densities reflect a secondary fracture porosity, then the density increase presumably reflects closure, and perhaps annealing of the fractures at greater depths. This would occur where the combination of lithostatic and tectonic stresses exceeds the internal pore pressure. The fact that the density increase occurs at different (lesser) depths from west to east (570-620 meters, Site 440; 560 meters, Site 441; 500 meters, Site 434) may imply either that internal pore pressures (at a given depth) increase toward the trench axis, or possibly that equivalent tectonic stresses are encountered at successively lesser depths, west to east. This pattern is corroborated by the veining and fracturing which occurs progressively higher in the column at Sites 440, 441, and 434 (von Huene and others, this volume).

Sonic velocity normally varies with bulk density, increasing as density increases, and decreasing as density declines. This pattern has been widely used (Hottmann and Johnson, 1965; Fertl, 1976; and many others) to delineate low-density zones in the sedimentary column. On the Japan Trench slope, however, observed lowdensity zones may (Site 434, Figure 8 ) or may not (Site 440 , Figure 5 ) be reflected in the velocity profile. The cause of this inconsistent response is not known, al- though it may be related to the presence of a fracture, rather than an interstitial, porosity.

We do not imply by this discussion that tectonic modification of the deposits of the inner trench slope is the only factor contributing to their anomalous nature. The generally rapid accumulation $\left(100-200 \mathrm{Mg} / \mathrm{m}^{2} / \mathrm{m}\right.$.y.) of sediment at Sites 440,441 , and 434 , in contrast to lower accumulation rates ( $\leq 50 \mathrm{Mg} / \mathrm{m}^{2} / \mathrm{m}$.y.) on the deepsea terrace (Sites 438 and 439) and the outer trench slope (Site 436), may contribute to the underconsolidated (high porosity, low density) character of the inner-slope deposits.

There can be little question that the physical properties of the Japan Trench inner slope deposits are anomalous. It is not clear, however, what combination of factors (lithology, rate of sediment accumulation, rate of tectonic compression) has contributed to the distribution and to absolute values of the various properties. It is apparent, however, that trench-slope sediments at a rapidly converging margin are not necessarily highly dewatered or overconsolidated. Indeed, the data from this margin indicate that poorly permeable, diatomaceous sediments which are subject to rapid lithostatic and tectonic loading may not consolidate quickly, but exist as thick, overpressured (?), underconsolidated sedimentary units.

\section{REFERENCES}

Bouma, A. H., and Moore, J. C., 1975. Physical properties of deep-sea sediments from the Philippine Sea and Sea of Japan. In Karig, D. E., Ingle, J. C., et al., Init. Repts. $D S D P, 31$ : Washington (U.S. Govt. Printing Office), 535568.

Carson, B., 1977. Tectonic modification of deep-sea sediments at the Washington-Oregon continental margin: mechanical consolidation. Mar. Geol., 24, 289-307.

Fertl, W., 1976. Abnormal Formation Pressures: New York (Elsevier).

Hamilton, E. L., 1976. Variations of density and porosity with depth in deep-sea sediments. J. Sediment. Petrol., 46(2), 280-300.

Hottman, C. R., and Johnson, R. K., 1965. Estimation of formation pressure from log derived shale properties. $J$. Petrol. Technology, 17(6), 717-722.

Lee, H. J., Olsen, H. W., and von Huene, R., 1973. Physical properties of deformed sediments from Site 181. In Kulm, L. P., von Huene, R., et al., Init. Repts. DSDP, 18: Washington (U.S. Govt. Printing Office), 897-901.

Reynolds, E. B., 1970. Predicting overpressured zones with seismic data. World Oil, October 1970, 78-82.

Stosur, J. J., and David, A., 1975. Petrophysical evaluation of the diatomite formation of Lost Hills, California. Paper presented at 50th Ann. Mtg., Society of Petroleum Engineers of AIME, Dallas, Texas. 